Jahangirnagar University J. Biol. Sci. 7(2): 79-88, 2018 (December)

\title{
Nutrient status of soil and regenerated Garjan (Dipterocarpus turbinatus Gaertn.) seedlings in Dulahazara Garjan Forest, Cox's Bazar, Bangladesh
}

\author{
Huda, M. K.* and Chowdhury M. A. M. \\ Department of Botany, Chittagong University, Chittagong - 4331, Bangladesh
}

\begin{abstract}
Soil: Plant nutrient status in naturally regenerated garjan (Dipterocarpus turbinatus Gaertn.) seedlings of 3, 9, 15, 21, 27 and 33 months old were studied in twelve stands of three sites on late and early monsoon during 1994 to 1995 in Dulahazara garjan forest of Cox's Bazar forest division. Soil samples were collected from two profiles (i.e. top soil and sub soil) of twelve stands in three sites. Soil moisture content, $\mathrm{pH}$, texture, electrical conductivity, cation exchange capacity, organic carbon, total $\mathrm{N}$ and available $\mathrm{P}, \mathrm{K}, \mathrm{Ca}, \mathrm{Mg}, \mathrm{Mn}$ and $\mathrm{Fe}$ were determined. Soils were found to be silty loam to sandy loam with an average $\mathrm{pH}$ of 5.06. The average values of organic carbon and cation exchange capacity were $0.74 \%$ and 6.23 meq/100g respectively. The soils were poor in total nitrogen $\left(689 \mu \mathrm{g} \mathrm{g}^{-1}\right)$ and the average values of available mineral nutrients such as $\mathrm{P}, \mathrm{K}, \mathrm{Ca}, \mathrm{Mg}, \mathrm{Mn}$ and $\mathrm{Fe}$ in soil were 3.15, 53, 40, 47, 36 and $0.94 \mu \mathrm{g} \mathrm{g}^{-1}$, respectively. The soil in site $-\mathrm{S}_{2}$ appeared to be more fertile than those of site- $\mathrm{S}_{1}$ and site- $\mathrm{S}_{3}$. The average values of $\mathrm{N}, \mathrm{P}, \mathrm{K}, \mathrm{Ca}, \mathrm{Mg}, \mathrm{Mn}$ and $\mathrm{Fe}$ in leaf- bud were found to be $1.80,0.13,0.94,0.72,0.23,0.06$ and $0.014 \%$ respectively. Leaf-bud nutrients showed a marked variation both with seasons as well as ages. Leaf-bud of late monsoon contained higher concentrations of $\mathrm{P}, \mathrm{Mg}$ and $\mathrm{Ca}$ compared to leaf-bud of early monsoon which contained higher concentrations of $\mathrm{N}, \mathrm{K}$ and Fe. Nutrient cycling in soil:leafbud system of regenerated garjan seedling of 3-33 months old varied with seasons and ages. The present study reveals that concentrations of $\mathrm{Mn}$ were significantly correlated between leaf-bud and soil whereas $\mathrm{P}$ showed the negative correlation indicating that in spite of low quantity of $\mathrm{P}$ in the soil, leaf bud had higher quantity.
\end{abstract}

Key words: Garjan seedlings, nutrient status, seedling ages, soil.

\section{INTRODUCTION}

Garjan (Dipterocarpus turbinatus Gaertn.) is a lofty evergreen tree, attaining a height of about $46 \mathrm{~m}$ and a girth of about $5 \mathrm{~m}$ with a long clean cylindrical bole and an elevated crown (Troup, 1921). It is indigenous to Bangladesh and is also distributed throughout the greater part of Indo-Malayan region (Troup, 1921; Gamble, 1922). Nutrient cycling is very important for natural regeneration, establishment, growth and development of a tree species. The rotation period of a tree species is usually long and the same nutrients usually are recycled and translocated in a regular sequence (Lambert \& Turner, 1989; Helmissari, 1992). Foliar analysis has been found to be useful for understanding nutrient supply of forest soils because other methods such as stem or bark analysis appear to be less reliable. Variation in foliar nutrient concentrations within the same species due to tree age, age of leaf, development stage, crown diameter, position of leaves in the crown, crown height, canopy closer, season and for growing in differentially fertile soils were reported (Helmissari, 1990). Helmissari (1990) observed that the concentrations of N, P, $\mathrm{K}, \mathrm{Ca}, \mathrm{Mg}, \mathrm{Mn}, \mathrm{Cu}, \mathrm{Zn}, \mathrm{Fe}, \mathrm{B}$ and $\mathrm{Al}$ in Scots Pine needle varied between seasons and

\footnotetext{
* Corresponding author. E-mail: mkhuda70@hotmail.com
} 
years, and reported that this variation was related to nutrient mobility as well as annual physiological cycles. The environment of the evergreen broad-leaved forests in Taiwan differs from that of temperate forests and tropical rain forests in many ways (Hsieh et al., 1998). Extreme soil acidity seems likely to account for the low stature of tropical upper montane rain forests (Grubb, 1977). Soil organic matter is a critical component of a terrestrial ecosystem (Chen \& Hseu, 1997). A substantial amount of organic matter usually returns to the forest floor through leaf-fall together with other parts of the trees. Litter fall plays a vital role in the transfer of energy from the autotrophs to the major heterotrophs and vise versa and thereby regulate the nutrient cycling and soil development. It is a fact that nutrient cycling does affect the growth of developing seedlings but seed germination and seedling establishment of a tree species is important for its sustainable development. With this view in mind, the present investigation was undertaken to study the nutrient status of garjan seedlings leaves of different ages that will be helpful for understanding the nutrient cycling pattern of the plants. Similarly evaluation of nutrient status of the soil of that area will indicate the feasibility and suitability of soils for growing garjan. Thus nutrient cycling patterns in soil: plant system of naturally regenerated garjan seedlings of varying ages in natural garjan forest floor of Cox's Bazar will explore a new dimension of natural garjan regeneration maintaining harmony with edaphic factors.

\section{MATERIALS AND METHODS}

The nutrient status of the terminal leaf-bud of the regenerated seedlings of different ages and the nutrient content of the soils surrounding the roots of the regenerated garjan (Dipterocarpus turbinatus Gaertn.) seedlings were determined to account for the nutrient cycling in the soil-plant system of the regenerated seedlings. Regeneration status and density of garjan seedlings of the same area and age determination of garjan seedlings were investigated.

Study area: The study area $\left(20^{\circ} 41^{\prime}-20^{\circ} 44^{\prime} \mathrm{N}, 92^{\circ} 4^{\prime}-92^{\circ} 6^{\prime} \mathrm{E}\right)$ is situated on the eastern hilly side near the coast of Bay of Bengal, $72 \mathrm{~km}$ south of the port city Chittagong. The forest area lies 2 to $6 \mathrm{~m}$ higher from the surrounding plains. The annual rainfall in this area is $3499 \mathrm{~mm}$ and most rainfall between May and September. The mean annual temperature is about $25^{\circ} \mathrm{C}$ with mean monthly temperature varying from $15.5^{\circ} \mathrm{C}$ (January) to $33^{\circ} \mathrm{C}$ (May). The humidity is high (86- 96\%) except in the dry season (November to March). In the winter season (November to March) when the rainfall is low, sometimes there are heavy dew and thick mist. The topography is ragged. The terrain in the hills is extremely irregular. Most of the area is situated between $15.2 \mathrm{~m}$ and $45.7 \mathrm{~m}$ above the sea-level. The soil varies from loam to sandy loam on hilly ground. The sandy soil is often impregnated with iron giving a reddish or yellowish tinge. The soil is very porous and sandy in the Dipterocarp forest (Das, 1980).

Selection of site: The vegetation of the area consists of a lower-storey undergrowth comprising 180 species (Islam, 1996), a middle-storey of planted garjan of 45-50 years old, and an above storey of tall, giant and matured garjan trees of more than 100 years old which are naturally regenerated and endemic to this area. Dulahazara garjan forest of 
Cox's Bazar district was selected as experimental field on the basis of abundance of regenerated seedlings of various ages on almost the same type of topography in three studied sites namely Site- $S_{1}$, Site- $S_{2}$ and Site- $S_{3}$. Each site consisted of four stands those were selected randomly from the laid grid of the vegetation.

Description of site: Site- $S_{1}$ was on the north western part of Rhingbhong block under Fasiakhali beat, Fasiakhali range. This site was bounded by low land on the north and hilly forest on the east and consisted of a total area of 33 acres. This site was rich with mixed plantation of garjan (Dipterocarpus turbinatus), dhaki jam (Syzygium grande), teak (Tectona grandis) and several other tree species. Biotic interferences such as wood collection, leaf litter collection were low but grazing was common. The site was considered as relatively protected.

Site- $S_{2}$ was on western area of Dulahazara and comprised of a total area of about 20 acres and it was plain land with gentle sloping to the west. This site consisted of garjan and dhaki jam. The overall vegetation was dense. Soil erosion was very common to the northern part of this site. This site was disturbed by several biotic factors such as wood collection, grazing, browsing and paddling (boating).

Site- $S_{3}$ was on the western side of Site- $S_{2}$ which was hilly and slightly sloping to the east. This site, which was about 20 acres, was composed of gigantic garjan on the upper storey; middle storey was almost absent but herbs and shrubs covered the lower storey. Both biotic and abiotic disturbances such as rocks, light, moisture, soil nutrients etc. prevailed in the vegetation and soil erosion was negligible.

Collection, processing and analyses of soil: Soil samples were collected randomly from the top soil $(1-25 \mathrm{~cm})$ and sub/ sub surface soil $(26-50 \mathrm{~cm})$ at four different places of the stand. Four samples were considered as four replicates of a stand. On the other hand, four samples were also collected for one stand and made it composite for the stand. Soil moisture content was determined gravimetrically. Then soil samples were dried in the open air and ground. Samples passed through a $2 \mathrm{~mm}$ sieve and then stored in a cool dry place in the laboratory for analyses. Soil texture was determined by Bouyoucos Hydrometer Method and named according to soil texture class triangle (USDA, 1951). Soil $\mathrm{pH}$ and electrical conductivity were measured based on 1:2 soil/water suspension using calibrated digital $\mathrm{pH}$ meter and conductivity meter respectively. Organic carbon was determined by the Modified Oxidation Method of Walkley \& Black (1934). Total nitrogen (N) and Cation exchange capacity (CEC) of soils were determined by the MicroKjeldahl Distillation Method (Jackson, 1958). Available phosphorus (P) was extracted using $1 \mathrm{M}$ ammonium acetate $(\mathrm{pH} 7.0 \pm .05)$ and determined by Spectrophotometer (blue colour method of Jackson, 1958). Available potassium (K), calcium (Ca), magnesium $(\mathrm{Mg})$, manganese $(\mathrm{Mn})$ and iron $(\mathrm{Fe})$ were extracted using $1 \mathrm{M}$ ammonium acetate $(\mathrm{pH}$ 7.0土.05). $\mathrm{K}$ and $\mathrm{Ca}$ were measured by flame photometer and $\mathrm{Mg}, \mathrm{Mn}$ and $\mathrm{Fe}$ were determined by Atomic Absorption Spectrophotometer.

Collection, processing and analyses of leaf buds: Terminal leaf-bud of naturally regenerated garjan seedlings (first three leaves with unfold bud) of different ages $(1,2$ and 3 years) were plucked randomly from 3-5 seedlings of each stand of three different 
sites. The terminal leaf-buds were collected on two different periods (late monsoon and early monsoon) at 6-month intervals during the study period. The studied seedlings were grouped into 3 and 9 months old (1 year), 15 and 21 months old ( 2 years) and, 27 and 33 months old ( 3 years) which resulted in the seedlings being ranked into 6 different ages (Huda, 1996; Huda et al., 1997). Samples were air dried at room temperature, ground and were extracted by Sulfuric-peroxide $\left(\mathrm{H}_{2} \mathrm{SO}_{4}-\mathrm{H}_{2} \mathrm{O}_{2}\right)$ digestion mixture (Allen et al., 1986). N (Micro-Kjeldahl Method), P (Spectrophotometer), K, Ca (Flame Photometer) and $\mathrm{Mg}, \mathrm{Mn}, \mathrm{Fe}$ (Atomic Absorption Spectrophotometer) were determined. Statistical analyses were performed following standard methods and Microsoft Excel.

\section{RESULTS AND DISCUSSION}

Moisture content of the soils of Dulahazara garjan forest varied from 21.6 to $28.4 \%$ and percentages of sand, silt and clay also varied widely among the sites (Table 1). Soils were poor in organic carbon content with average values of 0.67 to $0.86 \%$ in the top soil and 0.53 to $0.84 \%$ in the sub-surface soil. Similar range of organic carbon contents in forested hill soils of this region has been reported (Hossain \& Chowdhury, 1984; Haque et al., 1989; Osman et al., 1992). Most of the soils in the southern hilly areas of Bangladesh contain less than 1\% organic carbon in surface soils (SRDI, 1976) that is also observed in the present study. CEC of the studied soils was ranging from 4.04 to .04 meq/100 gm with CV\% of 62.8 in topsoil of site $\mathrm{S}_{3}$ indicating more variation due to the nature of mixed type of vegetation and their litter fall. EC varied from 217 to 274 and total $\mathrm{N}$ contents were also low and the average values were 457 to $914 \mu \mathrm{g} \mathrm{g}^{-1}$ in the top soil and 549 to $914 \mu \mathrm{g} \mathrm{g}^{-1}$ in sub-surface soil (Table 1). $51 \%$ coefficient variance was found in the top soil of Site- $\mathrm{S}_{2}$ due to more erosion of that site. The soils of the three sites were acidic ( $\mathrm{pH}$ 5-5.1). There was little evidence that differences in soil $\mathrm{pH}$ and available $\mathrm{N}$ were responsible for the variation in forest growth (Hsieh et al., 1998). The soils were also poor in available nutrients particularly $\mathrm{P}$ where the highest value was only $4.29 \mu \mathrm{g} \mathrm{g}^{-}$

${ }^{1}$ which might affect the growth performance (Table 1).

The low $\mathrm{pH}$ and organic matter content may account for the low availability of phosphorus (Ali et al., 1982). The average values of K, Ca, and Mg in the collected soil samples were 43 to $58 \mu \mathrm{g} \mathrm{g}^{-1}, 18$ to $61 \mu \mathrm{g} \mathrm{g}^{-1}$ and 35 to $67 \mu \mathrm{g} \mathrm{g}^{-1}$ respectively. Relatively higher value of $\mathrm{Mg}$ than that of $\mathrm{Ca}$ in most soil samples may be due to inheritance from the parent materials. Fe and $\mathrm{Mn}$ concentration ranged from 0.39 to $1.57 \mu \mathrm{g} \mathrm{g}^{-1}$ and 8 to $53 \mu \mathrm{g} \mathrm{g}^{-1}$ respectively. Concentration of micronutrients was higher as the low $\mathrm{pH}$ increases the availability of the micro nutrients. Organic matter content, total $\mathrm{N}$ and available $\mathrm{P}, \mathrm{K}$ and $\mathrm{Ca}$ in forest soils have been reported earlier (Ali et al., 1982) were similar with present study. On the other hand, 8 to $113 \mu \mathrm{g} \mathrm{g}^{-1}$ of available Fe was reported from forest soils in the hilly areas of West Bengal (Ghosh \& Banerjee, 1979). However, the present study showed that the studied soils were richer in Mn but poorer in Fe. Variation in the concentration of Fe was highest (CV\% 94) amongst the sub-surface soils of site- $\mathrm{S}_{1}$. It might have occurred due to significant differences of Fe concentration within a limited area. $\mathrm{Ca}$ also showed similar differences amongst sites and soil profiles. 
Nutrient status, soil and regenerated Garjan seedlings, Garjan Forest, Bangladesh

83

Table 1. Physico-chemical properties of soils in three different sites of Dulahazara Garjan forest

\begin{tabular}{|c|c|c|c|c|c|c|c|c|c|c|c|c|c|c|}
\hline Soil & Site & Moisture & Texture & $\mathrm{pH}$ & EC & $\mathrm{OC}$ & CEC & Total N & \multicolumn{6}{|c|}{ Available nutrients, $\mu \mathrm{g} \mathrm{g}^{-1}$} \\
\hline profile & & content $\%$ & Classes & & $\mu \mathrm{S} / \mathrm{cm}$ & $\%$ & $\mathrm{meq} / 100 \mathrm{~g}$ & $\mu \mathrm{gg}^{-1}$ & $\mathrm{P}$ & K & $\mathrm{Ca}$ & $\mathrm{Mg}$ & Mn & $\mathrm{Fe}$ \\
\hline \multirow{9}{*}{$\begin{array}{l}\overline{0} \\
\text { ñ } \\
\text { ô } \\
\text { }\end{array}$} & $\mathbf{S}_{1}$ & 23.0 & \multirow{3}{*}{$\mathrm{SiL}$} & 5.05 & 240 & 0.86 & 4.83 & 708 & 2.37 & 57 & 42 & 40 & 52 & 1.12 \\
\hline & & \pm 3.34 & & \pm .08 & \pm 43 & \pm 0.21 & \pm 2.20 & \pm 227 & \pm .34 & \pm 11 & \pm 23 & \pm 6.9 & \pm 2.0 & \pm .91 \\
\hline & $\mathrm{CV} \%$ & 14.5 & & 1.6 & 18.0 & 24.4 & 45.5 & 32.0 & 14.3 & 19.3 & 54.8 & 17.3 & 3.8 & 81.3 \\
\hline & $\mathbf{S}_{2}$ & 25.6 & \multirow{3}{*}{$\mathrm{L}$} & 5.00 & 274 & 0.86 & 8.04 & 914 & 3.70 & 55 & 55 & 67 & 53 & 1.57 \\
\hline & & \pm 5.99 & & \pm .00 & \pm 38 & \pm 0.18 & \pm 3.60 & \pm 470 & \pm .62 & \pm 13 & \pm 16 & \pm 4.1 & \pm 1.3 & \pm 1.10 \\
\hline & $\mathrm{CV} \%$ & 23.4 & & 0.0 & 13.9 & 20.9 & 44.8 & 51.4 & 16.8 & 23.6 & 29.1 & 6.1 & 2.5 & 70.1 \\
\hline & $\mathbf{S}_{\mathbf{3}}$ & 21.6 & \multirow{3}{*}{$\mathrm{SaL}$} & 5.10 & 229 & 0.67 & 6.05 & 457 & 2.86 & 43 & 33 & 36 & 11 & 0.95 \\
\hline & & \pm 0.52 & & \pm .05 & \pm 16 & \pm 0.02 & \pm 3.80 & \pm 32 & \pm .44 & \pm 6.9 & \pm 14 & \pm 2.2 & \pm 2.3 & \pm .65 \\
\hline & $\mathrm{CV} \%$ & 2.4 & & 1.0 & 7.0 & 3.0 & 62.8 & 7.0 & 15.4 & 16.3 & 42.4 & 6.1 & 20.9 & 68.4 \\
\hline \multirow{9}{*}{ 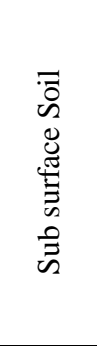 } & $S_{1}$ & 22.3 & \multirow{3}{*}{ SiL } & $5.08 \pm$ & 219 & 0.68 & 6.40 & 594 & 2.00 & 55 & 30 & 36 & 48 & 0.48 \\
\hline & & \pm 2.18 & & .16 & \pm 59 & \pm 0.11 & \pm 0.90 & \pm 226 & \pm .20 & \pm 6.3 & \pm 5.0 & \pm 5.7 & \pm 2.1 & \pm .45 \\
\hline & $\mathrm{CV} \%$ & 9.8 & & 3.1 & 26.9 & 16.2 & 14.0 & 38.0 & 10.0 & 10.9 & 16.7 & 15.8 & 4.4 & 93.8 \\
\hline & $\mathbf{S}_{2}$ & 28.4 & \multirow{3}{*}{ SiL } & 5.03 & 230 & 0.85 & 8.04 & 914 & 4.29 & 58 & 61 & 67 & 44 & 0.39 \\
\hline & & \pm 5.13 & & \pm .04 & \pm 34 & \pm 0.25 & \pm 4.10 & \pm 424 & \pm .62 & \pm 13 & \pm 26 & \pm 4.0 & \pm 3.2 & \pm .26 \\
\hline & $\mathrm{CV} \%$ & 18.1 & & 0.8 & 14.8 & 29.4 & 51.0 & 46.4 & 14.5 & 22.4 & 42.6 & 6.0 & 7.3 & 66.7 \\
\hline & $\mathbf{S}_{\mathbf{3}}$ & 21.6 & \multirow{3}{*}{$\mathrm{L}$} & $5.08 \pm$ & 217 & 0.53 & 4.04 & 549 & 3.65 & 45 & 18 & 35 & 8 & 1.13 \\
\hline & & \pm 1.31 & & .06 & \pm 31 & \pm 0.03 & \pm 0.10 & \pm 194 & \pm .08 & \pm 6.3 & \pm 12 & \pm 5.9 & \pm 0.6 & \pm .51 \\
\hline & $\mathrm{CV} \%$ & 6.1 & & 1.2 & 14.3 & 5.7 & 2.5 & 35.3 & 2.2 & 13.3 & 66.7 & 16.9 & 7.5 & 45.7 \\
\hline \multicolumn{2}{|c|}{ Mean } & 23.75 & & 5.06 & 234.8 & 0.74 & 6.23 & 689 & 3.15 & 52.17 & 39.83 & 46.83 & 36 & 0.94 \\
\hline
\end{tabular}

Legend: Data point is the mean of 12 samples; SiL=Silty loam; L= Loam; SaL= Sandy loam; EC= Electrical Conductivity;

$\mathrm{OM}=$ Organic matter; $\mathrm{OC}=$ Organic Carbon; $\mathrm{CV}=$ Coefficient Variance; \pm Standard Error 
Results of the present study indicate that regenerated garjan seedlings seemed to have individual preferences for different nutrients at different ages and in different periods. Leaf-buds of the seedlings at different ages possessed, however, the highest concentration of $\mathrm{N}$ among the nutrients studied with the values from 1.62 to $1.95 \%$ (Table 2). K concentration ( 0.882 to $1.008 \%$ ) followed $\mathrm{N}$ concentration in the leaf-bud (Table 2). Among the macro-nutrients, $\mathrm{P}$ concentration at all age classes was ranging from 0.117 to $0.149 \%$. Concentration of $\mathrm{Mn}$ varied from 0.043 to $0.085 \%$ and was comparatively greater than that of $\mathrm{Fe}$, which ranged from 0.012 to $0.016 \%$ (Table 2). Ca and $\mathrm{Mg}$ concentration presented in Table 2 were comparatively higher in the leaf-bud of garjan. Chowdhury (1995) studied the foliar nutrients of some forest tree species (e.g. Albizia lebeck, Artocarpus chaplasha, Cassia siamea, Emblica officinalis, Lagerstroemia speciosa, Swietonia mahogani, Syzygium grande) in the Chittagong University campus and foliar nutrients ranged from $1.11-3 \%$ of $\mathrm{N}, 0.22-0.31 \%$ of $\mathrm{P}, 0.55-1.23 \%$ of $\mathrm{K}, 0.61-$ $1.78 \%$ of $\mathrm{Ca}, 0.43-0.75 \%$ of $\mathrm{Mg}, 0.02-0.04 \%$ of $\mathrm{Fe}$ and $0.004-0.07 \%$ of $\mathrm{Mn}$ in the above mentioned tree species. Concentration of $\mathrm{N}, \mathrm{P}, \mathrm{K}, \mathrm{Ca}, \mathrm{Mg}, \mathrm{Fe}, \mathrm{Mn}$ and $\mathrm{Zn}$ in the leaf litter of Dipterocarpus turbinatus was found $0.64 \%, 0.1 \%, 0.23 \%, 0.35 \%, 0.19 \%$, $0.0152 \%, 0.0549 \%$ and $0.0084 \%$ respectively (Uddin, 1992). Present study also indicates the similar range of foliar nutrient status. Coefficient variance \% was ranging from 0.62 (in $\mathrm{P}$ of Site $\mathrm{S}_{2}$ ) to $35.55 \%$ (in $\mathrm{Mn}$ of $\mathrm{Site}_{3}$ ) for all nutrients of Leaf-bud, because the average mean value of the different sites is the values of different age classes of garjan seedlings and different seasons of the year.

Table 2. Nutrients content (\%) in the terminal buds of Garjan seedlings of three different sites in Dulahazara Garjan forest

\begin{tabular}{c|c|c|c|c|c|c|c}
\hline \multirow{2}{*}{ Site } & \multicolumn{7}{c}{ Nutrients, \% } \\
\cline { 2 - 8 } & $\mathrm{N}$ & $\mathrm{P}$ & $\mathrm{K}$ & $\mathrm{Ca}$ & $\mathrm{Mg}$ & $\mathrm{Mn}$ & $\mathrm{Fe}$ \\
\hline $\mathrm{S}_{1}$ & 1.950 & 0.149 & 1.008 & 0.695 & 0.218 & 0.085 & 0.012 \\
& \pm 0.523 & \pm 0.015 & \pm 0.235 & \pm 0.105 & \pm 0.008 & \pm 0.026 & \pm 0.000 \\
$\mathrm{CV} \%$ & 26.83 & 9.99 & 23.37 & 15.05 & 3.57 & 30.96 & 0.57 \\
\hline $\mathrm{S}_{2}$ & 1.620 & 0.117 & 0.882 & 0.704 & 0.241 & 0.054 & 0.014 \\
& \pm 0.523 & \pm 0.001 & \pm 0.170 & \pm 0.120 & \pm 0.008 & \pm 0.013 & \pm 0.003 \\
$\mathrm{CV} \%$ & 32.30 & 0.62 & 19.24 & 17.08 & 3.46 & 25.11 & 23.40 \\
\hline $\mathrm{S}_{3}$ & 1.830 & 0.132 & 0.923 & 0.757 & 0.216 & 0.043 & 0.016 \\
& \pm 0.651 & \pm 0.010 & \pm 0.120 & \pm 0.122 & \pm 0.016 & \pm 0.017 & \pm 0.004 \\
$\mathrm{CV} \%$ & 35.55 & 7.50 & 13.02 & 16.07 & 7.20 & 39.47 & 24.75 \\
\hline Mean value & 1.800 & 0.132 & 0.938 & 0.719 & 0.225 & 0.060 & 0.014 \\
\hline
\end{tabular}

Legend: Data point is the mean of 24 samples (all ages and seasons were averaged).

CV- Coefficient Variance; \pm Standard Error

Concentrations of $\mathrm{K}$ and $\mathrm{Mg}$ in leaf-bud increased with increasing age of the seedlings but $\mathrm{Fe}$ concentration in leaf-buds showed a reverse sequence (Figure 1). $\mathrm{Mg}$ is a constituent of the chlorophyll molecule and thus more concentration can be found in the comparatively older leaf-bud, on the other hand, Fe is needed for better metabolism in the younger plant. The status of macro-nutrient concentrations of regenerated seedlings fall within the range obtained for both indigenous and exotic forest trees planted in and around the locality (Osman et al., 1992; Sikder, 1993). From the data of present study, it is difficult to comment on whether the concentrations of micro-nutrients of leaf bud are in the optimum level or not. But the growth of the regenerated seedlings was fairly good and healthy in the study sites. So, leaf micro-nutrient concentration of the regenerated seedlings was adequate for the healthy growth. Zech \& Drechsel (1992) suggested 
deficiency levels of foliar $\mathrm{N}, \mathrm{P}, \mathrm{Mg}$ and $\mathrm{Mn}$ to be less than 1.5, 0.07, 0.09 and 0.02 per cent respectively for different broad-leaved species in Liberia. Hence, it is evident that the levels of nutrient concentration of leaf-buds of the regenerated garjan seedlings do not show lower values compared to the available data.

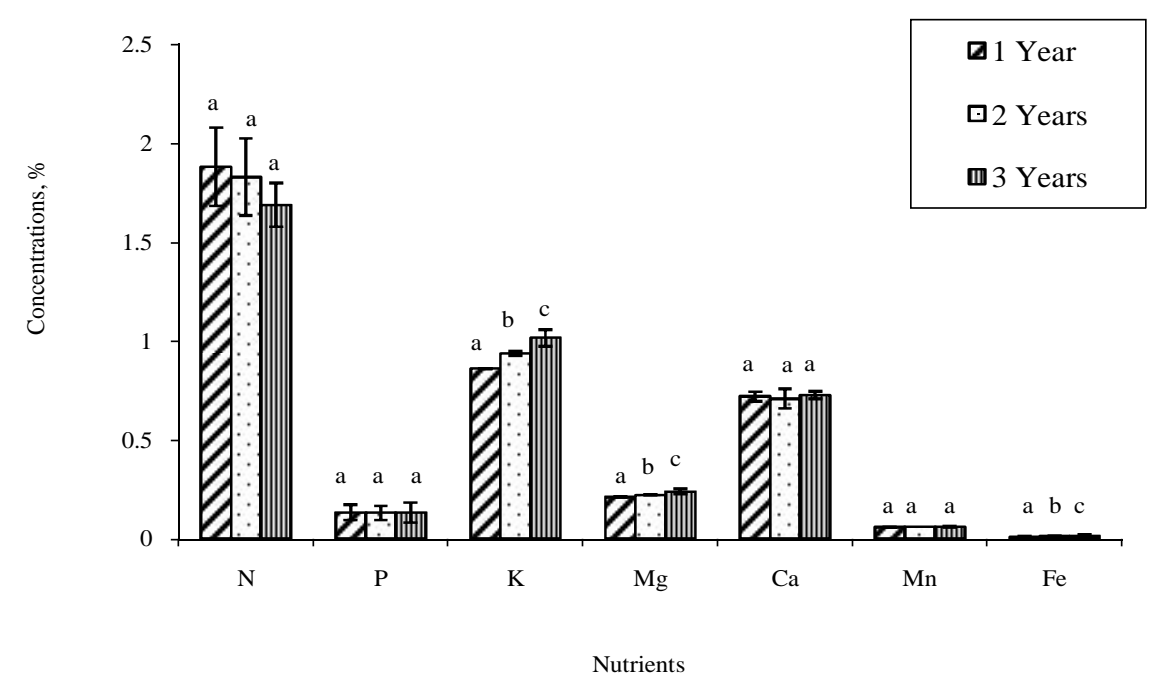

Fig. 1. Variation of nutrient content in leaf-bud of garjan seedlings at three age groups in Dulahazara Garjan Forest (a, b, and c indicate significant differences with each other)

Concentration of $\mathrm{N}$ in the leaf-bud of garjan seedlings was greater in the early monsoon than in the late monsoon whilst $\mathrm{P}$ and $\mathrm{Ca}$ concentration were higher in the late monsoon than early monsoon (Figure 2). Probable reasons might be due to absorption of more $\mathrm{P}$ and $\mathrm{Ca}$ which became available to the plant after shower (late monsoon). Helmissari (1990) observed variations in N, P, K, Ca, Mg, Fe and Mn concentrations in Pinus sylvestris needles between seasons and years. This variation was related to nutrient mobility and the annual physiological cycle, where the concentrations of the mobile nutrients such as N, P and K decreased in spring and early summer and increased in late summer and autumn, which reveals that needle nutrients concentration were stable during the non-active period. $\mathrm{N}$ concentration of the present study exhibited similar results with that of Helmissari (1990). Bockheim \& Leide (1991) obtained higher concentrations of $\mathrm{N}, \mathrm{P}, \mathrm{K}, \mathrm{Mg}$ and $\mathrm{S}$ in mid-summer on foliage of Pinus banksiana and Quercus ellipsoidalis growing on sandy and nutrient poor soils. Variation in nutrient concentration with seasons was also observed with Eucalyptus fastigata (Knight, 1988), Abies fraseri (Hockman et al., 1988) and Abies pinsapo (Sanchez et al., 1987).

Study on nutrient cycling in soil-plant system of regenerated garjan seedlings reveals that the concentrations of $\mathrm{Mn}$ in soils were positively correlated $(\mathrm{r}=0.76, \mathrm{df}=8$ and $\mathrm{p}<0.05$ ) with those of leaf-bud (Table 3) indicating that availability of $\mathrm{Mn}$ in the plant is depends on their availability in the soil. On the other hand, concentration of $\mathrm{P}$ in soils was negatively correlated $(\mathrm{r}=-0.77, \mathrm{df}=8$ and $\mathrm{p}<0.05)$ with the concentration of $\mathrm{P}$ in leaf-bud of garjan seedlings (Table 3). Table 2 shows that $\mathrm{P}$ concentration were found to be 
optimum in the leaf -bud of garjan in spite of low $\mathrm{P}$ concentrations in the soil because $\mathrm{P}$ is the important structural component of leaf-bud. Dipterocarpus turbinatus returned the maximum amount of $\mathrm{Fe}, \mathrm{Mn}$ and $\mathrm{P}$ to the soil, on the other hand, the same species returned considerably less macro-nutrients (Uddin, 1992). Seth \& Bhatnagar (1960) reported that $\mathrm{N}$ concentration in leaves of Shorea robusta was inversely related to concentration in the soil where the Ca contents of soil and leaf were found to be parallel to each other rising up to poor regeneration stand; however, no such regular trend was found to be exhibited by $\mathrm{Mg}$ and $\mathrm{P}$.

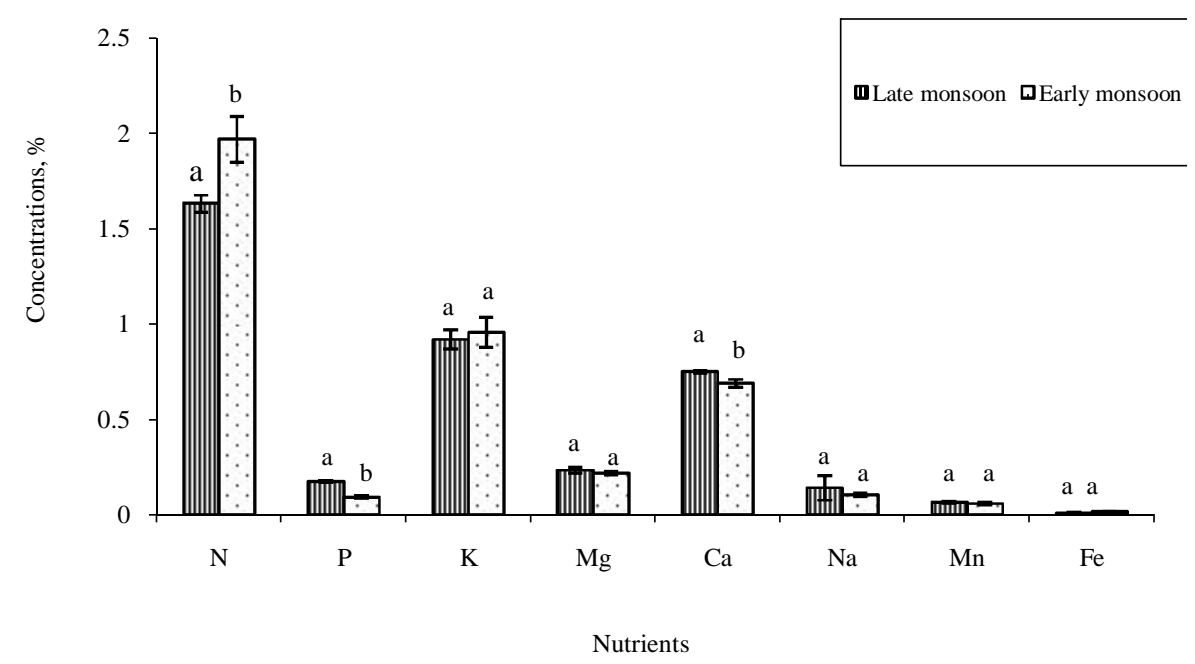

Fig. 2. Variation of nutrient content in leaf-bud of garjan seedlings on late and early monsoon in Dulahazara Garjan Forest (a, b, and c indicate significant differences with each other)

Table 3. Correlation coefficient between nutrients of leaf-bud of Garjan seedlings and soil in Dulahazara Garjan forest

\begin{tabular}{c|c|c}
\hline Independent variable, X (Soil) & Dependent variable, Y (Leaf-bud) & Correlation Coefficient, $\mathrm{r}$ \\
\hline $\mathrm{N}$ & $\mathrm{N}$ & -0.07 \\
$\mathrm{P}$ & $\mathrm{P}$ & $-0.77^{*}$ \\
$\mathrm{~K}$ & $\mathrm{~K}$ & -0.07 \\
$\mathrm{Ca}$ & $\mathrm{Ca}$ & -0.13 \\
$\mathrm{Mg}$ & $\mathrm{Mg}$ & 0.39 \\
$\mathrm{Mn}$ & $\mathrm{Mn}$ & $0.76^{*}$ \\
$\mathrm{Fe}$ & $\mathrm{Fe}$ & -0.50 \\
\hline
\end{tabular}

Legend: * indicates significant at $5 \%$ level $(\mathrm{P}<.05)$; Correlation between 12 samples.

On the basis of the above mentioned results, it is concluded that overall nutrient status of soils in different sites of the Dulahazara garjan forest was moderately low and the different nutrients in leaf-buds of successfully regenerated garjan seedlings fluctuate with seasons and age of seedlings. In the soil: leaf-bud system of regenerated garjan seedlings, $\mathrm{Mn}$ concentration in leaf-bud is associated with concentration of $\mathrm{Mn}$ in soil whilst $\mathrm{P}$ concentration in leaf-bud is inversely associated with the status of $\mathrm{P}$ in soil. 
Acknowledgement: The authors are grateful to the Director, Bangladesh Forest Research Institute, Chittagong for his kind permission to use Atomic Absorption Spectrophotometer and Divisional forest officers, Cox's Bazar Forest Division for their help in the course of field work.

\section{REFERENCES}

Ali, M.I., Bhuiya, E.H., Rahman, M.M. and Habibullah, A.K.M. 1982. Studies on the plant nutrient status in Bangladesh soils. Bangladesh J. Agril. Sci. 9(1): 25-39.

Allen, S.E., Grimshaw, H.M. and Rowland, A.P. 1986. Chemical analysis. In : Methods in Plant Ecology. Moore, P.D. and Chapman (Eds.) S.B. 2nd editions. Blackwell scientific publications. pp. 285-344.

Bockheim, J.G. and Leide, L.E. 1991. Foliar nutrient dynamics and nutrient use efficiency of Oak and Pine on a low fertility soil in Wisconsin. Canadian J. For. Res. 21(6): 925-934.

Chen, Z.S. and Hseu, Z.Y. 1997. Total organic carbon pool in soils of Taiwan. Proc. National Sci. Council ROC. Part B: Life Sci. 21(3): 120-127.

Chowdhury, M.R.U. 1995. Foliar nutrient concentration of seven forest trees and their periodic variations. M. Sc. Thesis, Department of Botany, University of Chittagong, Chittagong. pp 137.

Das, S. 1980. Dipterocarp forest of Bangladesh and their management. Bano Biggyan Patrica. 9 (I \& II): 71-86.

Gamble, J.S. 1922. A manual of Indian Timber. An account of the growth, distribution and uses of the trees and shrubs of India and Ceylon with description of their wood structure, Sampson low, Marston and com. ltd. London, 1981. Rept. 1922: 69-73.

Ghosh, R.C. and Banerjee, S.K. 1979. Distribution of different forms of iron in some soils of West Bengal. Indian Forester. 105: 773-778.

Grubb, P. J. 1977. Control of forest growth and distribution on wet tropical mountains: with special reference to mineral nutrition. Annual Rev.Ecol. Syst. 8: 83-107.

Haque, S.M.S., Hossain, A.T. M. E., Islam, A.T.M.N. and De, H.B. 1989. Characterization of forest soil of seed orchard and adjoining teak plantation at Hyanko. Bano Biggyan Patrica. 18(1\& II): 18-25.

Helmissari, H.S. 1990. Temporal variation in nutrient concentrations of Pinus sylvestries needles. Scand. J. For. Res. 5(2): 177-194.

Helmissari, H. S. 1992. Nutrient retranslocation in three Pinus sylvestries stands. Forest Ecological Management. 51(4): 347-367.

Hockman, J.N., Buryer, J.A. and Smith, D.W. 1988. Special and temporal variability of foliar nutrient levels in fraser fir Christmas trees. Forest Science. 35(2): 632-639.

Hossain, M.K. and Chowdhury, M.A.M. 1984. Studies on the undergrowth of teak (Tectona grandis) at Ichamati Forest Beat, Chittagong. 1. A preliminary survey on some soil properties and floristic composition of teak undergrowth. Chittagong University Studies. Part II. 8(1): 79-86.

Hsieh, C.F., Chen, Z.S., Hseu, Y.M., Yang, K.C. and Hsieh, T.H. 1998. Altitudinal zonation of evergreen broad leaved forest on Mount Lopei, Taiwan. J. Veg. Sci. 9: 201-212.

Huda, M.K. 1996. Natural regeneration potential and nutrient cycling in garjan (Dipterocarpus turbinatus Gaertn. f.) of Dulahazara Garjan Forest. M. Sc. thesis, Department of Botany, Chittagong University. pp. 200.

Huda, M. K., Islam, A.S.M.T. and Chowdhury, M.A.M.. 1997. Natural regeneration potential and stand composition of garjan (Dipterocarpus turbinatus Gaertn. f.) of Dulahazara Garjan Forest, Cox's Bazar, Bangladesh. Indian Forester. 123(5): 395-404.

Islam, A.S.M.T. 1996. Studies on the undergrowths of Dulahazara Garjan (Dipterocarpus turbinatus Gaertn.f.) forest, Cox's Bazar, Bangladesh. M. Sc. thesis, Deparment of Botany, Chittagong University. pp. 180.

Jackson, M.L. 1958. Soil Chemical analysis. Prentice - Hall Inc. Engle Wood Cliffs. N.J. U.S.A. pp. 1-496. 
Knight, P.J. 1988. Seasonal fluctuation in foliar nutrient concentration in a young nitrogen deficient stand of Eucalyptus fastigata with and without applied nitrogen. NZJ. Forest Science. 18(1): 15-32.

Lambert, M.J. and Turner, J. 1989. Redistribution of nutrients in sub tropical rainforest trees. Proc. Linnean Society NSW III (1-4): 1-10.

Osman, K.T., Haque, S.M.S. and Mia, F. 1992. Above ground biomass and nutrient distribution in Acacia auriculiformis, Dipterocarpus turbinatus and Pinus caribaea plantations at Chittagong University hills. Indian J. Forestry. 15(3): 193-197.

Sanchez, P., Corral, L., Paneque, G., Merida, J. and Gonzalez, J.L. 1987. Contents and fluctuation of mineral nutrients in needles of Abies pinsapo from Grazalema pine wood (Cadiz, Spain). I. nitrogen, phosphorus and potassium. Investigation of Agricultural Product and Vegetable. 2(3): 321-335.

Seth, S.K. and Bhatnagar, H.P. 1960. Interrelation between mineral constituents of foliage. Soil properties, site quality and regeneration status in some Shorea robusta forests. Indian Forester. 86(10): 590-601.

Sikder, S. 1993. Foliar nutrient levels of six forest tree species in relation to soil nutrient availability. M. Sc. Thesis, Dept. of Botany. Chittagong University. pp 135.

SRDI. 1976. Reconnaissance Soil Survey, Sadar South Cox's Bazar sub division, Chittagong district (1973). Prel. Edn. Soil Resources Development Institute (Department of soil survey). Govt. of the People's Republic of Bangladesh. pp. 104.

Troup, R.S. 1921. The Silviculture of Indian Trees. Vol. 1, Clarendon Press, Oxford. pp. 30135.

Uddin, S.K. 1992. Litter fall and nutrient returns in four forest plantations of Chittagong University campus. M. Sc. Thesis, Department of Botany, University of Chittagong, Chittagong. pp. 147.

USDA. 1951. Soil Survey Manual. Agricultural Hand Book 18, U.S. Department of Agricultural, Washington. U.S.A. pp. 1-491

Walkley, A. and Black, C.A. 1934. An examination of the Detjareff method for determining soil organic matter and a proposed modification of the chromic acid titration method. Soil Science. 37: 29-38.

Zech, W. and Drechsel, P. 1992. Multiple mineral deficiencies in forest plantation in Liberia. Forest Ecological Management. 48: 121-143. 